\title{
Christianity and Abortion Rights
}

\author{
Rohini Hensman*
}

*Correspondence: rohinihensman@yahoo.co.uk

Peer review: This article has been subject to a double blind peer review process

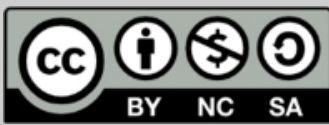

(c) Copyright: The Authors. This article is issued under the terms of the Creative Commons Attribution NonCommercial Share Alike License, which permits use and redistribution of the work provided that the original author and source are credited, the work is not used for commercial purposes and that any derivative works are made available under the same license terms.

\section{Abstract}

The struggle for abortion rights continues to rage in the 21st century. On one side feminists, who see it as part of the struggle to establish a woman's right to control her own body, and a wider constituency, who deplore the injury and death resulting from the lack of access to safe abortions, have campaigned energetically for abortion rights. On the other side, various religious fundamentalists have put pressure on states to block any expansion of rights and even take away existing rights. Prominent among the anti-abortion forces are the Roman Catholic establishment and rightwing Evangelical sects. Unable to find any prohibition of abortion in the scriptures, they have relied on the prohibition of murder, arguing that a fertilised ovum constitutes a human life, and therefore its destruction constitutes murder. This extreme anti-abortion position too finds no support in the Bible: indeed, even the Catholic church adopted it only in the latter part of the 19th century, and among Evangelicals it is much more recent, suggesting that it is part of the right-wing fundamentalist backlash against struggles for women's rights. Progressive Christians have been among those fighting for reproductive justice. Their arguments are compatible with the feminist position that having a baby should be a matter of choice, and that those who care for children should do so out of love, not compulsion. Thus reproductive justice is not only a matter of securing the right of women to make decisions about their bodies and their lives, but also a matter of securing the right of children to be loved and wanted. 
Keywords: abortion, feminism, Christianity, religious fundamentalism, women's rights, children's rights.

Feminists see abortion rights as part of the struggle to establish a woman's right to control her own body; for a wider constituency, it is also a demand for safeguarding the lives and physical and mental health of women and girls. ${ }^{1}$ Far from winding down, the struggle around abortion rights has, if anything, heated up in the twenty-first century. Women in several countries of the world have engaged in unprecedented organisational and outreach activities to win over other women and put the issue on the agenda of progressives. But the backlash has also been severe, and fundamentalists of various religions have been at the forefront of it (Eternity News, 2019). Christians are prominent among them.

There are countless Christian denominations with different positions on key issues including abortion, and there are contradictory positions even within each denomination. The most uniform is Roman Catholicism, where the Pope lays down the official anti-abortion stance, yet almost half of lay Catholics think that abortion should be legal. The Orthodox churches (Greek, Russian, Eastern, etc.) also have Patriarchs who oppose abortion, but a survey in the US showed that the majority of lay followers believe abortion should be legal (Pew Research Center, 2014). Mainline Protestant denominations - Anglicans (including US and Scottish Episcopalians, and Anglican churches in former British colonies), Methodists, Lutherans, Presbyterians, Congregationalists, the United Church of Christ and others - support abortion rights, although a small minority of followers do not (Markoe, 2018). Three-quarters of Evangelical Protestant denominations (sometimes known as 'born-again' Christians) oppose abortion, but a quarter do not. 


\section{The ongoing struggle for abortion rights}

Many countries in which abortion is severely restricted or abortion rights are under threat are ones in which the Catholic church has a strong presence. For example, more than 97 percent of women in Latin America and the Caribbean live in countries with restrictive abortion laws. Only in Cuba, Guyana, Uruguay and Mexico City is there abortion on demand during the first trimester, while in the Dominican Republic, El Salvador, Haiti, Honduras, Nicaragua and Suriname it is illegal under all circumstances. In most other countries of the region, including the rest of Mexico, it is legal only when the woman's or girl's life is at risk, or in cases of rape, incest or foetal anomaly (Guttmacher Institute, 2018). Even when abortion is legal, it is often unavailable to poor women and girls, or is denied for other reasons; for example, in 2007 in Peru, a 13-year-old girl who was pregnant after a neighbour raped her tried to commit suicide by jumping off a roof and was seriously injured; but she was not given the treatment she needed in case it induced a miscarriage, and remained a quadriplegic for the rest of her life (Gianella and Gloppen, 2014).

As a consequence, this region has the highest rate of illegal and unsafe abortions in the world. Somewhat surprisingly, however, many of the most stringent laws were introduced relatively recently, and have remained in force with the complicity of regimes self-defined as left-wing. For example in Chile, therapeutic abortions were banned in 1989, and never decriminalised after democratic regimes were established; Nicaragua adopted a total ban in 2006 in legislation supported by Daniel Ortega; in 1997, El Salvador adopted a total ban, with women who self-induced abortion or anyone who helped them liable to imprisonment for two to eight years; and in October 2013, Ecuador's president Rafael Correa threatened to resign if parliament decriminalised abortion for rape victims. This legal regime has its worst consequences for poor women and girls, who cannot afford private medical termination of their pregnancies 
and are therefore forced to rely on illegal abortions that are extremely unsafe (Gianella and Gloppen, 2014).

The huge number of women and girls seeking illegal abortions is one indication of popular resistance to this regime of enforced pregnancy, but there have also been organised protests. For example, women clashed with police in Ecuador after lawmakers failed to pass a bill that would have decriminalised abortion in cases of rape, incest and foetal malformation; activists pointed out that it was a death sentence for a large number of women and girls, given the alarming rates of rape (Daniels, 2019).

The most organised movement has taken shape in Argentina, where the National Campaign for the Right to Legal, Safe and Free Abortion was founded in 2005 to reform the 1921 law, which criminalised abortion unless the pregnancy threatened the life or health of the woman or was the result of rape. It received an enormous boost when the Ni Una Menos (Not One Less) movement, demanding an end to violence against women and girls, was born in 2015. The campaign has introduced legislation to legalise abortion in Congress every two years, but it was only on the seventh attempt in June 2018 that it obtained a narrow majority. That was a great victory for millions of activists with their trade-mark green handkerchiefs, but in August the bill was defeated in the Senate, and therefore failed to become law. Yet the momentum continued, with incoming president Alberto Fernandez, whose term started in December 2019, pledging to decriminalise abortion in 2020 (Caselli, 2020).

Much of the success of the movement comes from the fact that it has employed three strategies simultaneously. The first is legal reform, with the motto 'Sexual education to decide, Contraceptives to avoid abortion, Legal abortion so as not to die'. The second is a public health and rights strategy seeking to implement abortion availability in cases where it is legal under the existing law, as in the case of an 11-year-old girl, who had 
been raped by her grandmother's 65-year-old partner and made two attempts to commit suicide, yet was denied an abortion despite being entitled to it under existing legislation; this has involved working with the public health system, creating a network of feminist lawyers, and training judicial personnel to interpret the law in a manner that supports women's rights (Goñi, 2019). The third strategy of direct action and service provision aims at making safe abortion available to women with unwanted pregnancies regardless of the law; it involves two tracks: using hotlines and websites to provide information and assistance for women to self-induce abortions using medication; and health professionals providing medical abortions by arguing that all unwanted pregnancies are a threat to a woman's psychological health (Ruibal and Anderson, 2018).

The majority-Catholic country where the campaign for abortion rights has had the most spectacular victory is Ireland, where in a referendum on 25 May 2018, people voted by a decisive majority - 66 percent - in favour of repealing the Eighth Amendment to the Irish Constitution that made abortion illegal. The massive change in popular feeling can be gauged from the fact that the Eighth Amendment, effectively banning abortion by recognising the 'right to life' of the foetus, was also introduced as the result of a referendum in 1983, and even before that, getting a legal abortion in Ireland was not easy. It has been estimated that between 1980 and 2016 , more than 170,000 women travelled abroad to get abortions (Bardon, 2018). Those unable to do so had to resort to unsafe abortions or go through with their pregnancies, even when they were the result of rape or incest, or seriously threatened the life or health of the pregnant woman or girl.

A key event which energised the campaign for repeal was the death of 31year-old Savita Halappanavar in 2012. Seventeen weeks into her first pregnancy, Savita went to the University Hospital, Galway on 21 October 2012 with severe backache and lower abdominal pain, and was found to 
be having a miscarriage. After a day in agony and the rupture of her membranes, leaving her open to infection, she and her husband asked for a termination but were refused because there was a foetal heartbeat. Her condition deteriorated and she went into a coma, but nothing was done, and she died of septic shock on 28 October. The inquiry into her death was chaired by Professor Sabaratnam (2018), who testified that 'if a termination had been carried out when Savita and her husband had requested, she would not have had sepsis and she would be alive today.' The gratuitous cruelty with which an otherwise healthy young woman was subjected to an excruciatingly painful death in the name of saving the 'life' of an unviable foetus resulted in massive grief and outrage, which found an outlet in the campaign for abortion rights.

Another factor in the success of the campaign was revulsion against the crimes of the Catholic establishment, which will be examined in the next section. This probably changed the stance of the major parliamentary parties, which uniformly - from Fine Gael and Fianna Fáil to Labour and Sinn Féin - had supported the Eighth Amendment or failed to oppose it. But most critical was the all-out effort to mobilise the 'Yes' vote, which resulted in an unprecedented surge in voter registration before the referendum. It included crowd-funding to enable thousands of Irish women who had emigrated to travel home in order to vote, but 65 percent of men voted for it too. Young people aged 18-24 voted overwhelmingly (87 percent) in favour of Repeal (Holborow, 2018).

A key factor giving the Catholic Church power to impose measures, including opposition to abortion, contraception, relationship and sex education, and LGBT+ rights, is the status of the Holy See as the government of both the Catholic Church and the State of Vatican City. This allows treaties between the Holy See and other states, called 'concordats', to exempt Catholic institutions from being governed by the laws of the country. On the one hand concordats are often signed by states without 
prior scrutiny by elected parliaments, or by dictatorships, including those of Mussolini in Italy, Hitler in Germany, Salazar in Portugal, Franco in Spain and many others; on the other, the concluding article of a concordat states that it cannot be changed or abrogated without the agreement of the Vatican. This means that concordats outlive the governments and dictators who signed them, and continue to remain in place even if they violate a new democratic constitution and are incompatible with international human rights norms (Concordat Watch, n.d.).

In the United States, the assault on abortion rights has been spearheaded by right-wing Evangelical sects, which have succeeded in imposing increasingly restrictive abortion laws in state after state. In 2019, Ohio, Georgia, Kentucky and Mississippi passed bans on abortions once a foetal heartbeat has been detected, which could be as early as six weeks, when many women may not even know they are pregnant. Nine other states considered similar legislation, and Alabama passed an outright ban that would make providing an abortion a felony punishable by prison (Horton and Holpuch, 2019). Even where sweeping bans were successfully fought, defunding and enforced procedures - including compulsory questioning of women seeking abortions about their reasons for doing so, with some reasons (like Downs Syndrome) being outlawed, abortion clinics and helplines being forced to offer women anti-abortion literature, and the banning of abortion pills - have resulted in a drastic roll-back of abortion rights (Smith, 2019). The drive has been boosted enormously by help from the White House, with the Trump administration withdrawing funding for reproductive health support.

Evangelical opposition to abortion is quite recent. An examination of their publications and statements shows that 'the belief that life begins at birth was widely accepted as "the biblical view" among evangelicals only a few decades ago,' with some even advocating liberalisation of abortion laws (Dudley, 2019). So what changed? Not the Bible, although in typical 
fundamentalist fashion, the Evangelical Right has reinterpreted what it says and even tampered with translations. A common explanation is that the Christian Right emerged as a political movement in reaction to the US Supreme Court's 1973 Roe v. Wade ruling legalising abortion throughout the US, but Randall Balmer (2014) disagrees, noting that Evangelicals greeted the ruling with silence or even approval. Examining the timeline of Evangelical anti-abortionism, he notes that it emerged only in 1979, six years after the ruling, as part of a campaign to deny then president Jimmy Carter a second term. According to Balmer, the real issue motivating Evangelical leaders was the withdrawal of tax-exempt status from segregated Evangelical private educational establishments; but fearing that racial segregation might not be an issue on which they could rally their members, they fixed upon abortion, portraying Carter's refusal to promise a constitutional amendment outlawing it as 'an unpardonable sin'. Despite the merging of racism and anti-abortionism exemplified by Trump, for a significant section of Latinx voters and even some Black voters, opposition to abortion outweighs opposition to Trump's racism (Long-García, 2019; Lockhart, 2018).

The religious Right in the US has attacked abortion rights not just with legislation, withdrawal of funding, delicensing, cumbersome regulations and raucous demonstrations outside abortion clinics, but also with the murder of abortion providers and bombing of abortion clinics, a pattern of violence that resembles right-wing White-supremacist terrorism (Stack, 2015). Women activists, especially Black women, have responded by fundraising, volunteering to provide alternative reproductive healthcare services to women needing it, helplines telling women how they can access abortion, and accompanying and supporting women seeking abortions (Okeowo, 2019).

Policies of the Christian Right in the US have global consequences. Since 1973, the Helms Amendment, authored by Senator Jesse Helms, has 
prohibited US foreign aid being used for any abortion services. The Mexico City Policy or 'global gag rule,' adopted by Republican presidents starting with Ronald Reagan in 1984 and including Donald Trump, goes further, denying US funding to international reproductive health organisations providing abortion counselling, referrals or services, or advocating decriminalisation of abortion, even if this is done with non-US funding. As Marie Stopes International (2019) points out, the irony is that this actually increases the number of women undergoing abortions by depriving them of access to contraception.

In the US, the battle over abortion rights rages on into the 2020s. On one side, Trump nominated Amy Coney Barrett, member of the patriarchal, anti-abortion, fundamentalist Christian sect 'People of Praise,' to replace deceased liberal justice Ruth Bader Ginsburg in the US Supreme Court; on the other, the Abortion is Health Care Everywhere Act to repeal the Helms Amendment was introduced in Congress (Schakowsky, 2020).

Africa accounts for a devastating 62 percent of global abortion-related deaths, partly the legacy of colonial-era laws criminalising abortion unless it was to save a pregnant woman's life. In 2003, the landmark African Charter's Protocol on the Rights of Women in Africa, also known as the Maputo Protocol, attempted to bring these figures down by requiring governments to legalise medical abortion in cases of rape and incest, or where continuation of a pregnancy threatened the life or physical and mental health of a woman (Ngwena, 2014). Countries which ratified the protocol and liberalised abortion legislation did indeed reduce unsafe abortions, but improvements were hampered because these governments feared to publicise such legislation or implement it vigorously. Even NGOs working to provide abortions to women who needed them were afraid of provoking a backlash by campaigning openly, and instead worked behind the scenes to make maximum use of existing exceptions (for example, interpreting the 'risk to a woman's life' very liberally), and to help women 
to have abortions regardless of the law (Blystad et al., 2019). This fear was produced by the power of homophobic, anti-abortion Roman Catholic and Evangelical movements, themselves bolstered by interventions from the Christian Right in the US (Smith, 2012).

These are not the only countries where women are fighting back against assaults on abortion rights, but they are major examples of the way in which some Christian churches have spearheaded these assaults.

\section{What does the Bible say?}

The Bible is divided into the Old Testament, containing pre-Christian Jewish scriptures, and the New Testament, containing the Gospels, which describe the life and teachings of Jesus, and narratives of subsequent developments.

Numerous Bible scholars, like Rick Lowery (2012), testify that it says nothing about abortion. This is why Christian anti-abortionists have to argue that the embryo and foetus are full human persons, and therefore the prohibition of murder applies to them. Yet the Bible generally puts forward the view that life begins with the first breath and ends with the last. Old Testament case law expounding what should be done when a pregnant woman intervenes in a fight between her husband and another man and suffers injuries that cause a miscarriage says that if the miscarriage is the only injury, the other man must pay compensation, but if the woman dies, it is a capital crime and the man must pay with his life; in other words, the foetus is not yet a person, whereas the woman is. All this is completely compatible with the scientific and medical knowledge of the time. As Lowery comments, in the light of modern medical knowledge and procedures, we may need to modify this ancient view by specifying that once the foetus is fully viable and can survive outside the woman's body (around 24 weeks into the pregnancy), it should be regarded as a 
separate person. In principle, however, that should not affect the right of a woman to terminate her pregnancy whenever she wishes to do so, since before the foetus can survive outside her body it is not yet an independent life, and after it can survive outside her body it can be helped to do so, although late abortions are better avoided. In fact the Catholic church, including some of its most elevated saints, earlier allowed abortions until the 'quickening', when a woman began to feel foetal movements - in 1591 Pope Gregory XIV set the date at 166 days of pregnancy (almost 24 weeks) - and only in 1869 did Pope Pius IX prohibit all abortions (McGarry, 2013).

One can question whether the real purpose of anti-abortion church leaders is to move towards ending abortion. What would be the best way to achieve such a goal? Firstly, by making contraception widely and freely available, and secondly, through relationship and sex education that teaches young people to avoid unwanted pregnancies and condemns rape and incest. Yet this is precisely what these church leaders oppose. The Bible does not prohibit contraception; ${ }^{2} 80$ percent of the members of a Pontifical Commission held between 1963 and 1968 recommended accepting contraception, but were overruled by Pope Paul VI (McClain, 2018). For Evangelicals, opposition to contraception is even more recent. The Catholic hierarchy and right-wing Evangelicals came together in opposition to the clauses in President Obama's Affordable Care Act that made it mandatory for insurance schemes provided by employers to include free contraception - not that this prevented 68 percent of Catholic women and 74 percent of Evangelical women from using an IUD or hormonal contraceptive like the pill (Thomson-Deveaux, 2014).

As for relationship and sex education, many Catholic priests and right-wing Evangelicals have joined with other religious leaders to oppose schools teaching pupils to respect and value people equally regardless of sex, gender and sexual orientation. They have lobbied to have children withdrawn from these classes, and participated in virulent campaigns 
against teachers and schools standing by these values. The Vatican has issued sex education guidelines based on the notion that the ideal sexual relationship to be pursued by all is marriage between a man and a woman, indissoluble and open to life (i.e. rejecting contraception and abortion) (San Martín, 2016). Joining the Vatican and Muslim fundamentalists, the Evangelical Right has been part of a global campaign against relationship and sex education based on equality and inclusiveness, in some cases even trying to make it illegal (Hemery and Archer, 2019).

The illusion that there is anything 'pro-life' or 'pro-children' about any of this is dispelled when the fatal consequences of refusing to talk about safe sex in the context of the HIV-AIDS crisis is considered. Deaths like that of Savita Halappanavar and so many other women and girls denied medical termination of their pregnancies must also be included. The steadfast opposition of the Evangelical Right to gun control, despite the massacres (including many in schools) that have resulted from gun violence, can be traced to the same determination to defend the 'traditional family' that is expressed in their opposition to abortion and LGBT+ rights (Young, 2019). The Catholic establishment has sided with brutal dictatorships in Latin America which have incarcerated, tortured and killed thousands of dissidents. The large number of child sexual abuse cases against Catholic priests worldwide was supplemented by the systematic physical, sexual and emotional abuse of tens of thousands of children in Catholic institutions revealed by the 2009 Ryan report in Ireland, where the imprisonment in appalling conditions and slave labour of unmarried mothers in church-run 'Magdalene laundries' was revealed in 2013 by the McAleese report. Most gruesome of all was what happened to the babies of these women: 802 babies and children were buried at the Mother and Baby home in Tuam, County Galway, between 1925 and 1961 (Lonergan, 2019). Emer O'Toole (2017) points out the hypocrisy of attributing full personhood to embryos but not to women or children: 'Hundreds of dead babies are not an asset to those invested in the myth of abortion-free 
Ireland; they inconveniently suggest that Catholic Ireland always had abortions, just very late-term ones, administered slowly by nuns after the children were already born.'

It is abundantly clear, therefore, that the motivation for these antiabortionists is not a defence of life or love of babies but reinforcement of the patriarchal, authoritarian family modelled on their vision of the church. As Verónica Gago (2018) shows in her analysis of the abortion rights movement in Argentina, even Catholics who see themselves as exponents of Liberation Theology have the same attitude to poor women as the establishment, taking it upon themselves to make decisions on behalf of these women and claiming falsely that the demand for abortion is associated with neoliberalism and middle- and upper-class women, whereas it is in fact the demand of poor women fighting against neoliberalism. This shows that people who have progressive views on some issues may also have sexist, regressive attitudes that deny full personhood and agency to women and girls.

However, many Christians do not subscribe to these attitudes, and some have argued and campaigned explicitly against them. Rebecca Todd Peters, author of Trust Women: A Progressive Christian Argument for Reproductive Justice, an ordained minister in the Presbyterian Church and professor of religious studies at Elon University, points out that counterposing 'pro-life' to 'pro-choice' is a flawed paradigm because one is a theological position and the other is a legal one: they are incommensurable. She suggests instead a moral framework based on a foundation of reproductive justice, which recognises the right not to have a child, the right to have a child, and the right to raise children in a healthy and safe environment; ${ }^{3}$ she coins the term 'prenate' for the developing foetus, since she found that few women used the term 'foetus', and yet it was important to emphasise the distinction between a 'prenate' and a baby in order to argue that in many cases, abortion can be a morally good 
decision. This is a position compatible with her feminist interpretation of Christianity, but it could be equally compatible with other faiths or none (Russell-Kraft, 2019).

Willie Parker's trajectory was different. The fourth of six children of a Black single mother, he grew up in abject poverty, and despite all the obstacles stacked up against him became a doctor, specialising in obstetrics and gynaecology. A Christian who initially assumed that abortions were wrong, he explains in his memoir Life's Work: A Moral Argument for Choice that he became convinced that the freedom to take part in the reproductive process or not belongs as much to women as to men; forcing a woman to continue a pregnancy she wishes to terminate denies rights to a life that already exists, because if women and men have equal agency, women have the right to be self-governing, to have bodily integrity and moral authority to make decisions about their bodies, including decisions about reproduction. He points out that abortion is never mentioned in the Bible, and feels that 'the idea that life begins with the mere meeting of sperm and egg is offensive to God'; based on this belief, he 'continues providing safe and compassionate abortion care to the women who need it in the southern states where they are least likely to see their rights honoured Alabama, Georgia and Mississippi,' despite legal obstacles and threats to his life (Merelli, 2017). ${ }^{4}$

\section{Pregnancy, motherhood and mothering}

Pregnancy has been described as a 'biological war' between the embryo and the woman: on one side, the embryo punctures arteries and widens them to capture more blood, and pregnancy puts so much stress on the woman's body that even today, around 800 women die each day of pregnancy-related causes; on the other side, the woman's body attempts to protect itself from unviable embryos by making the endometrial wall of the uterus so difficult to penetrate that around half of pregnancies fail, 
mostly at the implantation stage (Sahedin, 2014). In other words, nature has no qualms about abortion, and even seems to require it in order to ensure the survival of the species. The way in which the embryo, and later the foetus, develops by taking oxygen and nutrition from the woman leaching calcium from her bones and exacerbating anaemia if she is undernourished - has led Catherine McKinnon (1991: 1314) to compare it to a parasite, although it is obviously not one. The physical demands on the woman continue after birth if the baby is breast-fed - which is ideal for the baby - and in the majority of cases, the mother also carries out most of the round-the-clock caring and nurturing of the infant and toddler, putting obstacles in the way of her doing any other work unless she can afford a nanny, or a nursery is available. In every way, her life is turned upside down.

This is why so much depends on whether the woman or girl wants the baby or not. ${ }^{5}$ If she does, then the discomfort of pregnancy, pain of childbirth, and associated risks are all worthwhile; if she doesn't, then they are inflicted on her against her will, along with the disruption of her life caused by having a baby. ${ }^{6}$ In Adrienne Rich's groundbreaking book Of Woman Born (1986/1976), she explains, 'I try to distinguish between two meanings of motherhood, one superimposed on the other: the potential relationship of any woman to her powers of reproduction and her children,' which she identifies as the practice of mothering, 'and the institution, which aims at ensuring that that potential - and all women - shall remain under male control.' In the long introduction to the 1986 edition of her book, Rich acknowledges the limitations of the White, middle-class perspective from which she wrote it; but despite these, her critique of the way in which women are oppressed by the assumption that childcare comes naturally to them and childrearing is the sole responsibility of the biological mother, even while she has no control over the conditions in which it is carried out, remains a powerful indictment of the institution of motherhood. 'Furthermore,' as Andrea O'Reilly (2004: 2-3) points out, 'Of Woman Born 
influenced the way feminist scholars theorize mothering-motherhood... In privileging subjective knowledge and by blending, blurring and bending the conventional oppositions of theory and experience, Of Woman Born cleared the way for a feminist narration of maternity in both literature and theory. ${ }^{7}$

In her last chapter, 'Violence: The heart of maternal darkness,' Rich links her critique of the institution of motherhood to the demand for autonomy and choice by showing how forced maternity, especially in cultures where unmarried mothers are despised, can lead to despair and a sense of having lost control, which can in turn lead to infanticide. Emily Jeremiah (2004) extends Rich's analysis by comparing it with Toni Morrison's novel Beloved, in which the mother, Sethe, kills her daughter in an attempt to save her from slavery: an act of love and resistance given the context of patriarchy and slavery, but one which haunts her. To such cases of deliberate infanticide we should add those in which unwanted children die of neglect and abuse at the hands of their mothers, their mothers' partners, their adoptive parents, or the institutions that take them away from their mothers, and those who die of malnutrition or disease because their poverty-stricken mothers are unable to provide for them. The children who die are only the tip of the iceberg; below them lie millions more who are damaged because their mothers are too overworked and harassed to give them the sustained loving attention they need, nor do others provide it. Finally, there are the child victims of rape, who are doubly traumatised or even at risk of dying if the pregnancy is continued, like the 10-year-old Brazilian girl persecuted by anti-abortion campaigners and forced to fly over 900 miles for an abortion after being raped (Phillips and Briso, 2020). When we add them up, it becomes evident that the issue of reproductive justice is not simply one of women's human rights but also of children's human rights. 
How, then, do we account for the vociferous Christian women who are part of the anti-abortion movement? It is likely that most of them lack enough knowledge of biology and the Bible to question the depiction of the foetus as a baby and abortion as infanticide. But Jes Kast, a woman who grew up in an Evangelical community and participated in antiabortion protests from the age of 12 , changed her mind on abortion when she began caring about racial justice, bodily autonomy and other justice issues; she eventually became a pastor in the United Church of Christ, serving on the clergy-advocacy board of Planned Parenthood (Green, 2019). So that leads us to another question: what prevents these women from questioning and rejecting their mistaken beliefs?

One possibility, especially for Catholic women, is that their community provides them with a sense of belonging and some degree of agency within a 'feminine' sphere of activity, which they could lose if they challenge the teachings of church leaders. In the case of the Evangelical Right in the US, a survey found that respondents who opposed abortion, including women, were significantly more likely to be hostile to gender equality (Filipovic, 2019); it is likely that having grown up in families where the father's authority goes unchallenged, they accepted women's subordination as right and proper. Women who are devoted followers of Trump, despite his overt sexism, are reminiscent of the Nazi women who were devoted to Hitler, despite the Nazi contempt for women, and proclaimed that National Socialism would restore women to their true profession: motherhood (Koonz, 1987: 72-77). In both cases, the racism and ultranationalism of the leaders probably constitute(d) an important element of their attractiveness to White women as well as men. Finally, the role of money: Norma McCorvey, the 'Jane Roe' of the Roe v Wade case, turned into an anti-abortion campaigner after becoming a bornagain Christian in 1995, but in 2016, shortly before she died, revealed that she had been paid at least $\$ 456,911$ by Evangelical leaders to switch sides (Horton, 2020). 


\section{Conclusion}

Despite setbacks in the struggle for reproductive justice, abortion laws globally were liberalised between 2000 and 2017. Twenty-seven countries expanded legal grounds for abortion to include protection of a woman's health, socioeconomic reasons, or without restriction as to reason, while only one country (Nicaragua) made abortion laws more restrictive; in addition, 24 countries approved at least one of three additional grounds for abortion: rape, incest and foetal anomaly. Improvements in the reach of safe abortion services and post-abortion care, even in highly restrictive contexts, means that fewer women are dying from unsafe abortion: 'Globally, the estimated abortion-related fatality rate (i.e. the number of deaths per 100,000 induced abortions) dropped by $42 \%$ between $1990-$ 1994 and 2000-2014, from 108 to 63' (Singh et al., 2018). This is still far too high, but it represents progress.

The struggle for reproductive justice continues, and Christians can be found on both sides of the divide. The relatively recent and totally arbitrary adoption of a hardline position opposing abortion by the Vatican and Evangelical Right fits the pattern of religious fundamentalist responses to the undermining of traditional hierarchies by democracy, which in all cases have a strong patriarchal component. The Evangelical Right's wholesale backing of Trump - a man who boasted about grabbing women 'by the pussy' - shows that their so-called 'family values' boil down to pure misogyny. Their strategy of seizing upon obscure Biblical passages and misrepresenting them to boost their own message while ignoring numerous passages that contradict their message is also straight out of the fundamentalist playbook. This conclusion is supported by research which found that 'increased religiosity - that is, taking your religion seriously and acting accordingly - actually increased support for abortion rights,' whereas 'religious orthodoxy, a.k.a. adherence to hard-line tenets, was strongly associated with opposition to abortion rights' (Jacobs, 2018). 
Having an abortion is not a pleasant experience, and no woman or girl would opt for it unless the alternative would be worse. Free and reliable contraceptives, in combination with relationship and sex education that teaches men and boys to respect the autonomy of women and girls and eliminates rape and incest, would result in a drastic reduction of the need for abortion, although it may still be necessary on rare occasions. Until then, however, its availability is crucial for ensuring the right of women and girls to make decisions about their own bodies and lives, and the right of children to be loved and wanted.

Rohini Hensman is a writer and independent scholar who comes from Sri Lanka and lives in India. She has written extensively on workers' rights, feminism, minority rights, globalisation, and struggles for democracy. Her books include Workers, Unions, and Global Capitalism: Lessons from India, and Indefensible: Democracy, Counter-Revolution, and the Rhetoric of Anti-Imperialism. She has also written two novels: To Do Something Beautiful, inspired by her work with working-class women and trade unions in Bombay, and Playing Lions and Tigers, which tells the interlocking stories of fourteen women, men and children confronting political authoritarianism and war in Sri Lanka.

\section{References}

Balmer, Randall (2014) 'The real origins of the religious right,' Politico, 27 May. https://www.politico.com/magazine/story/2014/05/religious-right$\underline{\text { real-origins-107133 }}$

Bardon, Sarah (2018) 'Fact check: Have more than 170,000 Irish women travelled abroad for an abortion?' The Irish Times, 2 May.

https://www.irishtimes.com/news/politics/fact-check-have-more-than170-000-irish-women-travelled-abroad-for-an-abortion-1.3481581 
Blystad, Astrid, Haldis Haukanes, Getnet Tadele, Marte E.S. Harland, Richard Sambaiga, Joseph Mumba Zulu and Karen Marie Moland (2019) 'The access paradox: abortion law, policy and practice in Ethiopia, Tanzania and Zambia,' International Journal for Equity in Health 18(126), 27 September. https://link.springer.com/article/10.1186/s12939-019$\underline{1024-0}$

Bullock, Maggie (2020) 'The \#MeToo case that divided the abortion-rights movement,' The Atlantic, March.

https://www.theatlantic.com/magazine/archive/2020/03/the-abortiondoctor-and-his-accuser/605578/

Caselli, Irene (2020) 'The birth of a movement: how activists are winning the battle to make abortion a right,' The Correspondent, 6 February. https://thecorrespondent.com/277/the-birth-of-a-movement-howactivists-are-winning-the-battle-to-make-abortion-a-right/36669679101$\underline{\operatorname{ad} 3 \mathrm{c} 0 \mathrm{da} 9}$

Concordat Watch (n.d.) 'What's the harm in concordats?' http://www.concordatwatch.eu/topic-47537.834

Daniels, Joe Parkin (2019) 'Clashes erupt after Ecuador fails to decriminalise abortion for rape victims,' The Guardian, 18 September. https://www.theguardian.com/globaldevelopment/2019/sep/18/clashes-erupt-after-ecuador-fails-todecriminalize-abortion-for-victims

Dudley, Jonathan (2019) 'When the "Biblical view" for Evangelicals was that life begins at birth,' Rewire.News, 27 September. https://rewire.news/religion-dispatches/2019/09/27/when-the-biblicalview-for-evangelicals-was-that-life-begins-at-birth/ 
Eternity News (2019) 'Jewish, Muslim and Christian leaders unite to oppose abortion bill,' 8 August.

https://www.eternitynews.com.au/australia/jewish-muslim-andchristian-leaders-unite-to-oppose-abortion-bill/

Filipovic, Jill (2019) 'A new poll shows what really interests "pro-lifers": controlling women,' 22 August.

https://www.theguardian.com/commentisfree/2019/aug/22/a-new-pollshows-what-really-interests-pro-lifers-controlling-women

Gago, Verónica (2018) 'Spirituality as a force of rebellion: the movement for legal abortion in Argentina,' Verso Blog, 18 June.

https://www.versobooks.com/blogs/3886-spirituality-as-a-force-ofrebellion-the-movement-for-legal-abortion-in-argentina

Gianella, Camila and Siri Gloppen (2014) 'Access denied: Abortion rights in Latin America,' Chr. Michelsen Institute, Brief 13(1), https://www.cmi.no/publications/5022-access-denied-abortion-rights-inlatin-america

Goñi, Uki (2019) 'Girl, 11, gives birth to child of rapist after Argentina says no to abortion,' The Guardian, 1 March.

https://www.theguardian.com/global-development/2019/feb/28/girl-11gives-birth-to-rapists-child-after-argentina-refuses-abortion

Green, Emma (2019) 'A pastor's case for the morality of abortion,' The Atlantic, 26 May.

https://www.theatlantic.com/politics/archive/2019/05/progressivechristians-abortion-jes-kast/590293/ 
Guttmacher Institute (2018) 'Abortion in Latin America and the

Caribbean,' March. https://www.guttmacher.org/fact-sheet/abortionlatin-america-and-caribbean

Hemery, Sophie and Nandini Archer (2019) 'UK Christian conservatives join "disastrous" global backlash against sex education,' OpenDemocracy, 12 September. https://www.opendemocracy.net/en/5050/uk-christianconservatives-join-disastrous-global-backlash-against-sex-education/

Holborow, Marnie (2018) 'Ireland's abortion victory: women's lives, the liberal agenda and the radical left,' International Socialism 160, 11 October. https://isj.org.uk/irelands-abortion-victory/

Horton, Adrian (2020) 'AKA Jane Roe: behind the headline-making abortion documentary,' The Guardian, 22 May.

https://www.theguardian.com/tv-and-radio/2020/may/22/aka-jane-roedocumentary-norma-mccorvey

Horton, Adrian and Amanda Holpuch (2019) 'We have to fight: Alabama's extreme abortion ban sparks wave of activism,' The Guardian, 17 May. https://www.theguardian.com/world/2019/may/17/we-have-to-fightalabamas-extreme-abortion-ban-sparks-wave-of-activism

Jacobs, Tom (2018) 'Sexism and religious fundamentalism drive opposition to abortion,' Pacific Standard, 11 July.

https://psmag.com/social-justice/sexism-and-religious-fundamentalismdrive-opposition-to-abortion

Jeremiah, Emily (2004) ‘Murderous Mothers: Adrienne Rich's Of Woman Born and Toni Morrison's Beloved', in Andrea O'Reilly (ed.), From Motherhood to Mothering: The Legacy of Adrienne Rich's Of Woman Born, Albany: State University of New York Press, pp.59-72. 
Koonz, Claudia (1987) Mothers in the Fatherland: Women, the Family and Nazi Politics, New York: St Martin's Press.

Lockhart, P.R. (2018) “"Abortion as genocide": inside the Black antiabortion movement,' Vox, 19 January.

https://www.vox.com/identities/2018/1/19/16906928/black-antiabortion-movement-yoruba-richen-medical-racism

Lonergan, Aidan (2019) 'Tuam babies inquiry finds local people "know more" about mass burial of 802 children than they told investigators,' The Irish Post, 17 April. https://www.irishpost.com/news/tuam-babiesinquiry-finds-local-people-know-mass-burial-802-children-toldinvestigators-166037

Long-Garcia, J.D. (2019) 'Why are Hispanic Catholics pro-life? What politics can't explain,' America Magazine, 16 September. https://www.americamagazine.org/politics-society/2019/08/28/whyare-hispanic-catholics-pro-life-what-politics-cant-explain

Lowery, Rick (2012) 'Abortion: What the Bible says (and doesn't say),' Huffpost, 14 September. https://www.huffpost.com/entry/abortionwhat-the-bible-says-and-doesnt-say b_ 1856049

Marie Stopes International (2019) 'The Global gag rule: A world without choice'. https://www. mariestopes.org/what-we-do/our-approach/policyand-advocacy/the-global-gag-rule-a-world-without-choice/

Markoe, Lauren (2018) 'Where are mainline Protestants on abortion?' Religion News Service, 18 January.

https://religionnews.com/2018/01/18/where-are-mainline-protestantson-abortion/ 
McClain, Lisa (2018) 'How the Catholic Church came to oppose birth control,' The Conversation, 9 July. https://theconversation.com/how-thecatholic-church-came-to-oppose-birth-control-95694

McGarry, Patsy (2013) 'Catholic Church teaching on abortion dates from 1869,' The Irish Times, 1 July. https://www.irishtimes.com/news/socialaffairs/religion-and-beliefs/catholic-church-teaching-on-abortion-datesfrom-1869-1.1449517

MacKinnon, Catharine A. (1991) 'Reflections on sex equality under law,' The Yale Law Journal 100, pp.1281-1328.

Merelli, Annalisa (2017) "'Abortion is never mentioned" in the Bible - A Christian ob-gyn on why choice is pro-life,' Quartz, 16 April. https://qz.com/959736/abortion-is-never-mentioned-in-the-bible-achristian-ob-gyn-on-why-choice-is-pro-life/

Ngwena, Charles (2014) Human Rights and African Abortion Laws: A Handbook for Judges, Nairobi: Ipas Africa Alliance.

Okeowo, Alexis (2019) 'Fighting for abortion access in the South,' The New Yorker, 7 October.

https://www.newyorker.com/magazine/2019/10/14/fighting-forabortion-access-in-the-south

O'Reilly, Andrea (ed.) (2004) From Motherhood to Mothering: The Legacy of Adrienne Rich's Of Woman Born, Albany: State University of New York Press.

Pew Research Center (2014) 'Views about abortion among Orthodox Christians' https://www.pewforum.org/religious-landscapestudy/religious-tradition/orthodox-christian/views-about-abortion/ 
Phillips, Tom and Caio Barretto Briso (2020) 'Brazil: outcry as religious extremists harass child seeking abortion,' The Guardian, 17 August. https://www.theguardian.com/world/2020/aug/17/brazil-protestabortion-recife-hospital

Rich, Adrienne (1986) Of Woman Born: Motherhood as Experience and Institution, New York: W. W. Norton \& Company.

Ross, Loretta and Toni M. Bond (2019) 'Calling in rather than calling out: When \#MeToo meets reproductive justice,' Rewire.News, 5 April. https://rewire.news/article/2019/04/05/calling-in-rather-than-callingout-when-metoo-meets-reproductive-justice/

Ruibal, Alba and Cora Fernández Anderson (2018) 'Legal obstacles and social change: strategies of the abortion rights movement in Argentina,' https://www.researchgate.net/publication/328833373 Legal obstacles and social change strategies of the abortion rights movement in $\mathrm{Ar}$ gentina

Russell-Kraft, Stephanie (2018) 'A Christian argument for abortion: A Q\&A with Rebecca Todd Peters,' The Nation, 11 April.

https://www.thenation.com/article/a-christian-argument-for-abortion-aqa-with-rebecca-todd-peters/

Sabaratnam, Arulkumaran (2018) 'Never Again!' Yes Repeal Referendum Special, Trade Union Campaign to repeal the $8^{\text {th }}$, p. 2 .

https://www.yumpu.com/en/document/read/60053485/yesrepealrefere ndumspecial 
Sahedin, Suzanne (2014) 'War in the womb,' Aeon, 4 August.

https://aeon.co/essays/why-pregnancy-is-a-biological-war-betweenmother-and-baby

San Martín, Inés (2016) 'Vatican issues its own sex ed guidelines,' Crux, 24 August. https://cruxnow.com/vatican/2016/08/vatican-issues-sex-edguidelines/

Schakowski, Jan (2020) ‘US anti-abortion policies endanger lives worldwide. Here's my plan to end that,' Rewire News Group, 29 July. https://rewirenewsgroup.com/article/2020/07/29/u-s-anti-abortionpolicies-endanger-lives-worldwide-heres-my-plan-to-end-that/

Singh, Susheela, Lisa Remez, Gilda Sedgh, Lorraine Kwok and Tsuyoshi Onda (2018) 'Abortion worldwide 2017: Uneven progress and unequal access,' Guttmacher Institute Report, https://www.guttmacher.org/report/abortion-worldwide-2017

Smith, David (2012) 'US evangelical Christians accused of promoting homophobia in Africa,' The Guardian, 24 July.

https://www.theguardian.com/world/2012/jul/24/evangelical-christianshomophobia-africa

Smith, Kate (2019) 'Missouri's 8-week abortion ban was blocked, but these new restrictions are still going into effect,' CBS News, 28 August. https://www.cbsnews.com/news/missouri-abortion-law-missouriabortion-ban-was-blocked-down-syndrome-ban-goes-into-effect-today2019-08-28-live/

Stack, Liam (2015) 'A brief history of deadly attacks on abortion providers,' The New York Times, 29 November. 
https://www.nytimes.com/interactive/2015/11/29/us/30abortion-clinicviolence.html

Starkey, Marian and John Seager (n.d.) 'Loretta Ross: Reproductive justice pioneer, co-founder of Sistersong Women of Color Reproductive Justice Collective,' Population Connection.

https://www.populationconnection.org/article/loretta-ross/

Thomson-Deveaux, Amelia (2014) 'The strange bedfellows of the anticontraception alliance,' The American Prospect, 17 March.

https://prospect.org/power/strange-bedfellows-anti-contraceptionalliance/

Young, Neil J. (2019) 'Why do evangelicals oppose gun control?' The

Week, 11 August. https://theweek.com/articles/857806/whyevangelicals-oppose-gun-control

\section{To cite this article:}

Hensman, R. (2020). Christianity and Abortion Rights. Feminist Dissent, (5), 155-182. Retrieved from: https://doi.org/10.31273/fd.n5.2020.763

\section{Notes}

${ }^{1}$ An estimated 25 million women and girls have unsafe abortions every year. Around 22,800 die as a consequence, and many of those who survive suffer long-term damage (Marie Stopes International, 2019).

${ }^{2}$ The Old Testament story of Onan is often cited as prohibiting contraception and masturbation, but it does nothing of the sort. In it, God kills Onan for 'spilling his semen on the ground' in order to avoid 'raising up an heir' for his deceased elder brother by impregnating his childless sister-in-law, as commanded by his father Judah. According to Leviticus 15: 16-18, the only penalty for nocturnal emissions, masturbation or coitus interruptus is that the man (or man and woman) must bathe with water, and be considered unclean till evening. 
${ }^{3}$ This definition of 'reproductive justice' was first articulated at a conference in 1994 by a group of African-American women who were advocating a more holistic approach to reproductive rights that included social justice and human rights, and it became the basis of their activism (Starkey and Seager, n.d.).

${ }^{4}$ In March 2019, Parker was accused of sexual assault by abortion-rights activist Candice Russell. She was not working with him but was 20 years younger (he was 52, she was 32). In an exhaustive investigation, Maggie Bullock (2020) found that Russell alleged in an essay that in October 2016 he had sex with her while she was drunk; she also alleged that he was a serial predator, but Bullock found no evidence of other assaults; and that she had received hundreds of abusive emails in response to her article, but was unable to produce them. Parker, who as a result of the allegations lost his position on boards of various reproductive-rights organisations and was no longer invited to conferences and talks, said that she made him sound like the stereotypical sexualised black man; he didn't buy her any drinks on that occasion; and she showed no signs of being intoxicated. Black feminists Loretta Ross (who had been director of the first rape crisis centre in the USA) and Toni M. Bond (2019), founders of the reproductive justice framework, cautioned that while sexual assault survivors should be able to name perpetrators without fear of retribution, there was also a danger of violating the human rights of the accused, given that 'the court of public opinion has never been a fair process, especially for people of color,' and therefore called for 'a process that seeks to unearth the truth'.

${ }^{5}$ The third possibility - commercial surrogacy, where the woman wants the pregnancy but not the baby - cannot be considered here. And of course an unplanned pregnancy can produce a wanted baby.

${ }^{6}$ Disclosure: I loved babies from an early age, welcomed my first two pregnancies, and adored my babies when they were born. But when I got pregnant for a third time due to failure of my IUD, after my children started going to school and I had begun going out to work again, I was astonished at the wave of dismay and resentment that swept over me. There were economic reasons for the dismay - even with my income, we could hardly make ends meet - but the resentment was because I found my work satisfying, felt it was socially useful, and didn't want to give it up. Luckily for me, it was Indian government policy to encourage women in my position to terminate their pregnancies and get tubal ligation, so I was provided with both procedures at no cost. I still love babies, but have never regretted that abortion.

${ }^{7}$ I have reservations about the use of the term 'mothering' for the nonpatriarchal nurturing of children. After an infant is weaned, a man can do everything for a baby that a woman can do, and even before that can bottlefeed the baby with formula or expressed breast milk. There are cases where a man - either gay or heterosexual - is desperate to have a baby and a woman agrees to go through with a pregnancy provided he does the bulk of caring for the child. Challenging the gender division of labour in childcare is an important way of undermining the patriarchal institution of motherhood, and the term 'mothering' is too gendered to do that. 